\title{
JURISPRUDENCE OF STATE ADMINISTRATIVE COURTS IN THE DEVELOPMENT OF STATE ADMINISTRATIVE LAW
}

\author{
Aju Putrijanti \\ Faculty of Laws of Diponegoro University \\ Corresponding email: ajuputrijanti@lecturer.undip.ac.id \\ Paper received on: 21-02-2021; Revised on: 02-05-2021; Approved to be published on: 04-05-2021 \\ DOI: http://dx.doi.org/10.30641/dejure.2021.V21.161-174
}

\begin{abstract}
State Administrative Courts is a judicial body that has absolute competence to examine and resolve disputes in the field of state administration. The development of State Administrative Courts (Peratun) jurisprudence is indispensable for the development of state administrative law. The problems studied are the role of jurisprudence in the field of state administrative law and the role of State Administrative Courts in providing access to justice. This research is a normative legal research where primary and secondary legal materials are analyzed qualitatively. The Supreme Court has made efforts to strengthen jurisprudence so that it can support the development of administrative law. Judges' decisions are needed as a source of law. This is because it comes from dynamic legal dispute resolution. Then, jurisprudence can bring about social change for society. The process of making judges' decisions is also faster than the process of drafting laws. The broader absolute competence of State Administrative Courts can provide easy access to justice where the public can file complaints against factual actions of the Government in the field of public law. Jurisprudence as a source of law is indispensable for developing state administrative law by taking into account the development of society, social conditions, legal and political conditions. Jurisprudence produces general principles of good governance so that it can be used for the administration of government wisely.
\end{abstract}

\section{Keywords: State Administrative Courts; access to justice}

\section{INTRODUCTION}

The concept of a rule of law has existed since the time of Plato, which began with his work, The Republic. Then, this work was perfected by Aristotle who stated that the law is needed to achieve a better human life. The rule of law is needed to run a government that begins with the basic law or the state constitution ${ }^{1}$.

Civil Law and Common Law are two concepts of rule of law that often arise and have different characteristics. Civil Law originated from Continental European countries. Stahl pointed out the characteristics of a rule of law or rechtsstaat, namely the existence of a government based on regulations to prevent absolutism, protection of citizens' human rights, an administrative court that is tasked with examining any administrative violations committed by the government and a clear distribution of power $^{2}$. Historically, the

Enrico Simanjuntak, "Relevansi Pemikiran Negara Hukum Dalam Diskursus Keadilan Administratif Kontemporer," in Rekonseptualisasi Kewenangan Pengadilan Tata Usaha Negara Dalam Mengadili Perkara Fiktif Positif (Depok: PT Rajagrafindo Persada, 2021), 61, http://www.rajagrafindo.co.id.

Despan Heryansyah and Kus Pratiwi, "Perluasan Kompetensi Absolut Pengadilan Tata Usaha Negara concept of Civil Law arose to limit the absolutism of the ruler's power so that there needs to be a firm regulation that limits the authority and clarity of the distribution of power. A.V. Dicey put forward the concept of Rule of Law which is based on the supremacy of law, equality before the law and constitution based on individual rights ${ }^{3}$.

Article 1 paragraph (3) of the 1945 Constitution of the Republic of Indonesia affirms that Indonesia is a rule of law. This means that all government administration is based on law, including the rights and obligations of the government and citizens. This has the consequence that there is recognition of equality before law and government, the principle of legality and the supremacy of law, guarantees of protection of citizens' rights, and the administration of a free and impartial trial. This is because the general principles of rule of law in the two concepts of rule of law are still applied, taking into account

Dalam Undang-Undang Administrasi Pemerintahan," Jurnal Hukum Ius Quia Iustum 25, no. 2 (2018): 339358.

3 Priyatmanto Abdoellah, Revitalisasi Kewenangan PTUN Gagasan Perluasan Kompetensi Peradilan Tata Usaha Negara (Yogyakarta: Cahaya Atma Pustaka, 2016).

Jurisprudence of State Administrative Courts Aju Putrijanti 
various factors in Indonesia. The existence of a state administrative courts shows that there is an element of rechtsstaat, while the recognition of equality before the law is an element of rule of law, so that Indonesia develops both concepts based on Pancasila . ${ }^{4}$

The rule of law in Indonesia has a special characteristic that is based on Pancasila. One of the main characteristics in the rule of law of Pancasila is the guarantee of freedom of religion, which according to Muhamad Tahir Azhary, although in the explanation of the 1945 Constitution uses the term rechtsstaat, what is adopted by Indonesia is not the concept of rechtsstaat or rule of law, but rather the concept of rule of law of Pancasila ${ }^{5}$. This shows that the basic values recognized by the Indonesian people have been implemented in government based on aspects of divinity, humanity, social justice, unity and deliberation as well as a dynamic active rule of law where state administrative disputes between citizens and the government must be resolved through a judicial body.

Independency of judicial power is an absolute requirement in a rule of law to uphold law and justice. The exercise of judicial power in Indonesia is the Supreme Court and the Constitutional Court, along with the judicial bodies that are under the Supreme Court. Judicial bodies under the Supreme Court are the General Courts, Religious Courts, Military Courts and State Administrative Courts which are established based on law and have absolute competence in carrying out their functions as judicial bodies.

Judicial body's decisions have binding force for the parties in a case and must be implemented after obtaining permanent legal force. In addition, these decisions can also form new legal norms for law development and formation. In the common law system, judicial body's decisions have a strong role in the establishment of laws so that the precedent of judge-made law develops, namely judges making laws. Decisions of judicial bodies in countries using the common law system have

\footnotetext{
4 Otong Syuhada, "Karakteristik Negara Hukum Pancasila Yang Membahagiakan Rakyatnya," Presumption of Law 3, no. April (2021): 1-18.

5 Tengku Erwinsyahbana and Tengku Rizq Frisky Syahbana, "Perspektif Negara Hukum Indonesia Berdasarkan Pancasila" (2018): 1-20, https://osf.io/ preprints/inarxiv/cwev7/.
}

an important role in law development because these decisions arise from disputes that go to court and are decided by judges.

The State Administrative Courts (hereinafter referred to as Peratun) which was formed based on Law Number 5 Year 1986 concerning State Administrative Courts has absolute competence to resolve state administrative disputes, namely disputes arising between individuals or civil legal entities with state administrative entities and/or officials at the central and regional levels as a result of the issuance of state administrative decisions. State Administrative Courts is highly needed to maintain government administration so that it is always in balance with the interests of the community and still provide legal protection for the community due to government actions that cause losses.

According to Bagir Manan, society needs regulations where laws and regulations are any written decision made by an authorized official that contains rules of behavior that are general in nature and can contain provisions regarding rights, obligations, functions, or an order, so that the laws and regulations are abstract ${ }^{6}$. Sometimes, the dynamics of a society that develop rapidly cannot be followed by existing laws. This is because the process of drafting laws and regulations takes a long time. The formulation of laws which requires a long and complicated process needs to be reviewed by looking at the fast-track legislation system used in several countries. There are several important things that need to be considered in a study that uses the fast-track legislation system? ${ }^{7}$. First, it must be regulated in the country's constitution regarding legality by removing the article on the President's authority to make a Government Regulation in Lieu of Law. Second, if it is regulated in legislation, it is stated that the submission can only be made by the President and a deadline for deliberation of the draft law is determined. Third, restrictions on the material of legislation to be discussed and the necessary

\footnotetext{
6 Insan Firdaus, "Harmonisasi Undang-Undang Narkotika dengan Undang-Undang Pemasyarakatan Terkait Rehabilitasi Narkotika Bagi Warga Binaan Pemasyarakatan," Jurnal Penelitian Hukum De Jure 21, no. 1 (2021): 141-160.

7 Ibnu Sina Chandranegara, "Pengadopsian Mekanisme FastTrack Legislation Dalam Pengusulan Rancangan UndangUndang Oleh Presiden," Jurnal Penelitian Hukum De Jure 21, no. 1 (2021): 123
} 
procedures must still pay attention to public access. Fourth, the loading of the sunset clause. Fifth, if it does not include the sunset clause, then the obligation to review the legislation against the draft law that has been passed using the fast-track legislation mechanism can be stated. Sixth, this mechanism is prohibited from being used for the omnibus law method.

The attitudes or ways of punishing the community in dealing with cases have also experienced a more advanced shift compared to five decades ago, such as the level of legal awareness to settle cases in the judicial body which has increased. Public interest in resolving state administrative disputes also shows that citizens can sue the Government to overturn state administrative decisions. In addition, the community can also use the State Administrative Courts as a means of obtaining justice.

The development of state administrative disputes at this time is very interesting, namely the widening of absolute competences so as to make it easier to obtain access to justice. Before Law Number 30 Year 2014 concerning Government Administration (hereinafter referred to as the UU AP) was passed, there were very limited restrictions on the types of disputed objects that could be submitted to the State Administrative Courts. This also has an impact on the difficulty of society in obtaining justice. Types of disputed objects that can be filed a lawsuit in accordance with Law Number 5 Year 1986 concerning State Administrative Courts in conjunction with Law Number 9 Year 2004 concerning Amendments to Law Number 5 Year 1986 concerning State Administrative Courts in conjunction with Law Number 51 Year 2009 concerning The Second Amendment to Law Number 5 Year 1986 concerning State Administrative Courts (hereinafter referred to as the UU Peratun) is a state administrative decision which has concrete, individual and final characteristics. The main demand that is being requested from the State Administrative Courts is the cancellation of the disputed object and may be accompanied by additional demands in the form of compensation.

State Administrative Courts' Decision may impose an obligation to revoke the object of dispute or to revoke the object of dispute and issue a new state administrative decision or issue a state administrative decision if the lawsuit is based on
Article 3 of the State Administrative Courts Law. Court decisions can also give birth to new legal norms that are in line with the dynamics of the dispute being decided. Court decisions that have gained permanent legal force can still be a source of law in the administration of government. As stated in Article 10 Paragraph (1) and (2) of the Law of Government Administration, General Principles of Good Governance (AUPB) derived from court decisions with permanent legal force can still be used as AUPB.

In general, the development of court decisions in Indonesia can be used as a guide for judges in deciding cases with the same opinion. However, the use of court decisions to serve as a basis or guideline for government administration has not been used optimally. This is because there is still a strong understanding that the law as the highest legislative hierarchy after the Constitution and made by an authorized institution has general binding force. Meanwhile, the public is of the view that court decisions only have binding force for the disputing parties. They do not understand that it is possible for a new legal norm to arise from such decision.

The previous research on the jurisprudence of State Administrative Courts judges carried out by Teguh Satya Bhakti argued that the decision of State Administrative Courts Judge which can be referred to as jurisprudence must meet several conditions, namely a decision on an event whose regulation is unclear, a decision that has permanent legal force, repeatedly decided for the same case, fulfilling a sense of justice, is justified by the Supreme Court and containing an obiter dicta and ratio decidendi and State Administrative Courts Judges must have the ability of thought and professionalism to improve the quality of decisions by observing the real conditions in society ${ }^{8}$. Judges are demanded to be able to give decisions that can resolve disputes by taking into account and considering the development of society so that the resulting decisions have effectiveness.

The results of Enrico Simanjuntak's research state that apart from filling the legal vacuum, the function of jurisprudence is also important to create the same legal standard or legal certainty

\footnotetext{
8 Teguh Satya Bhakti, "Pembangunan Hukum Adminisitrasi Negara Melalui Pemberdayaan Yurisprudensi Peradilan Tata Usaha Negara" (Universitas Diponegoro, 2017).
} 
so that Judge decisions can be more open and predictable?.

The novelty in this article is that jurisprudence has an important role, namely forming new legal rules that can bring about social change for society. In addition to providing easier access to justice for the public, the expanded absolute competence of State Administrative Courts can also lead to the emergence of general principles of good governance, which is necessary to improve governance.

Based on the explanation above regarding the jurisprudence of State Administrative Courts Judges, there are two issues that will be investigated. First, how is the development of State Administrative Courts Judge jurisprudence in the development of state administrative law? Second, what is the role of State Administrative Courts in gaining access to justice for the society?

\section{RESEARCH METHOD}

The research method used is normative legal research using a historical approach, a conceptual approach, a statute approach and comparative law. The historical approach is important because to find out the background of the use of jurisprudence in Indonesia, the conceptual approach was carried out by examining and analyzing legal concepts that are relevant to the problem and using the opinions of experts and doctrines. The statute approach is to make an inventory, systematize and evaluate the relevant laws and regulations. The comparative law approach is to study the position of administrative courts in the legal systems of other countries.

The primary legal materials used are laws and regulations related to the problems. Secondary legal materials consisted of court decisions, scientific articles and relevant scientific papers. The data was collected by conducting an inventory of primary and secondary legal materials that are relevant to the problems. The obtained data was then grouped according to the problems. Then, the data was analyzed descriptive-qualitatively.

9 Enrico Simanjuntak, "Peran Yurisprudensi Dalam Sistem Hukum Di Indonesia The Roles of Case Law in Indonesian Legal System," Jurnal Konstitusi 16, no. 1 (2018): 83-104.

\section{DISCUSSION AND ANALYSIS}

A. The Role of Jurisprudence in the Development of State Administrative Law

According to Zevenbergen, sources of law can be divided into two, namely formal and material sources of law ${ }^{10}$. Sources of formal law are places or sources of regulations that gain force in society, in the form of laws, jurisprudence, treaties and doctrines. Material sources of law are factors that determine the content or material from which legal material is taken or factors that help form the law, for example socio-cultural, political, geographic, and economic factors ${ }^{11}$.

Historically, Indonesia followed the legal system under colonial rule, namely civil law or Continental Europe which prioritized law as the main legal source. Meanwhile, jurisprudence has the meaning of a court decision that has permanent legal force and is followed by other judges in the same case. Judges are better known as funnel of law (la bouche de la loi), because they are not bound to follow the previous judge's decision (not binding precedent). Judges in the civil law system impose decisions that must be based on law in addition to other legal sources. This resulted in the judge being unable to provide any other interpretation apart from what was stated in the law.

In the Indonesian legal system, when the judicial body was formed, jurisprudence was more often used in civil or criminal cases by using the Hoge Raad decision as the highest judicial institution during the colonial period. For the State Administrative Courts system, jurisprudence is carried out based on the State Administrative Courts decision that has gone through procedures by the Supreme Court of the Republic of Indonesia. The State Administrative Courts was formed in 1986 so that the Judge made legal findings.

The Supreme Court issued Supreme Court Circular Letter (SEMA) No. 2 Year 1972 concerning the Collection of Jurisprudence which states that the Supreme Court is the only constitutional institution responsible for collecting jurisdiction which Judges must follow

1o Fais Yonas Bo'a, "Pancasila Sebagai Sumber Hukum Dalam Sistem Hukum Nasional Pancasila as the Source of Law in the National Legal System," Jurnal Konstitusi 15, no. 1 (2018): 28-49, http://consrev.mkri. id/index.php/jk/article/view/1512.

" Ibid. 
in adjudicating cases. The Supreme Court Circular Letter No. 2 Year 1972 regulates technically the procedure for collecting and issuing jurisprudence and does not regulate the terms or criteria for a decision to be categorized as jurisprudence. Related to this, Enrico Simanjuntak conveyed two things ${ }^{12}$. First, it is necessary to emphasize the qualifications of jurisprudence because this is to publish landmark decisions. Second, there needs to be an explanation regarding permanent and variable jurisprudence because it is related to the similia similibus principle that must be fulfilled in every decision of the judicial body.

According to Sebastian Pompe, quoted from Enrico, there is a difference in meaning between precedent and jurisprudence. Precedent is a judge's decision that binds the next judge. Meanwhile, jurisprudence is the decision of the judicial body. In the Netherlands, there are provisions that require precedents to be followed. This has also been applied in France. However, the abuse of precedent use encourages codification. Charles J. Reid states that the essence of stare decisis or precedent is that the decision of the previous judicial body is not a law, but an authoritative principle of legal evidence.

The word "jurisprudence" in the common law system or anglo-saxon means law science. Meanwhile, judges' decisions followed by other judges and regularly followed are known as judge-made law or case law. In the common law system, judges can be freer to evaluate cases being examined and are bound by the previous judge's decision (the binding force of precedent). The decision that is made first will then become a source of law for the court and government administration, then the law contained in the judge's decision is called jurisprudence law or judge law or judgment law ${ }^{13}$.

The rapid and global development of society has made the difference in jurisprudence in civil law and the common law system is rarely debated so that it is not used differently. This is important to support changes in the dynamics of society, which

12 Enrico Simanjuntak, "Praktik Yurisprudensi Dan Kepastian Hukum Dalam Sistem Civil Law," in Perdebatan Hukum Administrasi Sebuah Kompilasi Artikel Hukum Administrasi (Jakarta: Gramata Publishing, 2017), 30-6o.

13 Theresia Ngutra, "Hukum Dan Sumber-Sumber Hukum," Jurnal Supremasi XI, no. 2 (2016): 193. require laws that can be used to solve problems that arise. Furthermore, according to Teguh Satya Bhakti, Judges of State Administrative Courts are required to be active in accordance with the dominus litis principle as a special principle in State Administrative Courts in order to provide justice for the disputing parties ${ }^{14}$.

The results of Henry Pandapotan Panggabean's research state that jurisprudence which is the result of legal discovery is expected to realize a legal standard for the establishment of legal classifications that create legal principles through judge-made law. It is also supported by the opinion of Yahya M Harahap that the role of judges as judge-made law has autonomy of freedom to carry out judicial functions that are increasingly developing in the midst of globalization ${ }^{15}$. The role of the Judges of State Administrative Courts is expected to be able to provide a decision which can later be used as law and binding the public.

The judge's decision is expected to provide a sense of justice, legal certainty and benefits to the society in relation to law enforcement. Judges must explore and understand legal values and a sense of justice that live in society, in order to make quality decisions and enforce the law. As one of the elements of law enforcement, judges have an important role in making decisions so that they can be of use to society. This is related to the nature of the erga omnes of the State Administrative Courts' decision.

In examining, deciding and resolving state administrative disputes, the State Administrative Courts Judges must also pay attention to the principle of balance between the government, individual interests, public or society interests and consider the weight of these interests so that a fair decision can be realized. Based on the dominus litis principle as one of the special principles in State Administrative Courts, the State Administrative Courts Judges can be active in examining state administrative disputes so that they can provide justice for the disputing parties.

At present, the development of jurisprudence related to state administrative law that originates

14 Bhakti, "Pembangunan Hukum Adminisitrasi Negara Melalui Pemberdayaan Yurisprudensi Peradilan Tata Usaha Negara."

15 Hulman Panjaitan, "Keberadaan Hukum Adat Dalam Yurisprudensi," Jurnal Hukum tô-râ 2, no. 3 (2016): 413-420. 
from the decision of the State Administrative Courts Judge has a strategic position because it has helped shape or build a better state administrative legal system. This can automatically provide legal certainty. Cassation decisions related to the same can be seen from the website of the Supreme Court, namely No. 421 K/TUN/2016 followed by case decisions No. $74 \mathrm{~K} / \mathrm{TUN} / 2017$ and $269 \mathrm{~K} / \mathrm{TUN} / 2018$ with legal principles in the form of improvements to state administrative decisions by government officials may not be detrimental to the interests of other parties who obtain state administrative decisions legally and in good faith. Judicial Review Decisions No. $13 \mathrm{~B} / \mathrm{PK} / \mathrm{PJK} / 2013$ followed by case decisions No. $61 \mathrm{~B} / \mathrm{PK} / \mathrm{PJK} / 2013,62 \mathrm{~B} / \mathrm{PK} / \mathrm{PJK} / 2013$, $12 \mathrm{~B} / \mathrm{PK} / \mathrm{PJK} / 2015,6604 \mathrm{~B} \quad / \mathrm{PK} / \mathrm{PJK} / 2018$, $605 \mathrm{~B} / \mathrm{PK} / \mathrm{PJK} / 2018,11 \mathrm{~B} / \mathrm{PK} / \mathrm{PJK} / 2015,607$ B/PK/PJK/2018, 436 B/PK/PJK/2014, 10 B/ $\mathrm{PK} / \mathrm{PJK} / 2015,40 \mathrm{~B} / \mathrm{PK} / \mathrm{PJK} / 2014,434 \mathrm{~B} / \mathrm{PK} /$ $\mathrm{PJK} / 2014,435 \mathrm{~B} / \mathrm{PK} / \mathrm{PJK} / 2015$, with the legal principle that the provisions in the Contract of Work are lex specialis of the applicable law ${ }^{16}$.

As stated in Article 5 paragraph (1) of Law Number 48 Year 2009 concerning Judicial Power, it is stated that Judges are obliged to explore, follow and understand legal values and the sense of justice that exist in society. This is further linked to Article 10 paragraph (1) of Law Number 48 Year 2009 concerning Judicial Power that the Court may not refuse to examine, judge and decide cases on the pretext that the law does not exist or is unclear, but is obliged to examine and judge. Freedom of judicial power as the basis for judges to examine and decide cases is expected to provide justice and legal certainty and become jurisprudence.

Efforts to formulate the jurisprudence of State Administrative Courts Judge decisions have been initiated since 1992 and can be seen on the official website of each State Administrative Courts. First, the Judge can use this as a guide in examining and deciding similar cases. Second, the government can use jurisprudence in carrying out government duties and functions. Third, the public can find out about the existence of legal norms produced by court decisions. Fourth, academics

\footnotetext{
16 "Putusan Mahkamah Agung Republik Indonesia," http s://jdih.mah kamah agung.go.id/index. php?option=com_remository $\&$ Itemid $=46 \&$ func $=$ filein fo\&id $=4017$.
}

and legal practitioners can use jurisprudence for better scientific development.

State Administrative Courts jurisprudence began in 1992 on land, namely the Supreme Court first introduced the use of the ultra petita principle in state administrative disputes (decision No. $5 \mathrm{~K} /$ TUN/1992). The verdict states that the Judge not only examines the object of the proposed dispute, but must also assess and consider parts of the determination or decision of the State Administration Agency and/or Officials that are not disputed by the parties. The new legal rule is that it is possible to have ultra petita in the examination of state administration disputes. The judge can decide more than what is demanded by the Plaintiff with consequences, namely that it can bring the plaintiff to a more detrimental legal condition than before (reformatio in peius). The grace period for the Plaintiff is calculated from the time of acknowledging the existence of the impaired decision ${ }^{17}$. Then, the decision becomes jurisprudence as long as the claim can be proven by the Plaintiff in court.

The Law of State Administrative Courts does not regulate the use of ultra petita in Judges' decisions, with the existence of jurisprudence of decision No. 5K/TUN/1992, which gives enlightenment that the State Administrative Courts Judges can perform ultra petita. In subsequent developments, the State Administrative Courts Judges used ultra petita in the decisions to obtain substantial justice. In addition, it shows that jurisprudence has provided new things that benefit society. The application of ultra petita in the State Administrative Courts environment is possible as long as it is based on a clear legal basis and to achieve justice.

Jurisprudence is urgently needed to fill legal gaps that may arise in the administration of government and can serve as guidelines for the administration of government. The State Administrative Courts' jurisprudence on ultra petita has also developed with the various types of state administrative disputes that have emerged in line with the dynamics of government and society.

\footnotetext{
${ }^{17}$ Ayu Putriyanti Elisabeth Putri Hapsari, Lapon Tukan Leonard, "Kewenangan Hakim Peradilan Tata Usaha Negara Menggungakan Asas Ultra Petita Berdasarkan Putusan Mahkamah Agung No.5//K/TUN/1992 ( Stu di Kasus Putusan No. 32/G/2012/PTUN.Smg)," Diponegoro Law Journal 6, no. 2 (2017): 1-13.
} 
State administrative disputes that were proposed were very diverse. This is interesting because it can lead to a new legal rule from the Judge's decision. This dynamic condition requires court decisions that produce new legal rule where the role of judges is needed to carry out law reform through the judicial process. This court decision serves as a law as tool of social engineering, namely carrying out social change in society as stated by Roscoe Pound ${ }^{18}$. The new rules arising from the judge's decision can be used as a source of law in the implementation of government administration, as well as balancing the relationship between the government and the society.

In the implementation of government administration in an era of openness and advancement of information technology, the Government issued Law Number 14 Year 2008 concerning Public Information Disclosure, which guarantees the right of citizens to obtain public information. Public information disclosure can lead to public information disputes which can be resolved through the District Court or State Administrative Courts (see Article 47 of Law Number 14 Year 2008 concerning Public Information Disclosure). Based on Article 4 of Law Number 14 Year 2008, it is stated that everyone has the right to obtain public information in accordance with the provisions of the law. This is understood to mean actio popularis. Article 36 paragraph 1 letter $\mathrm{b}$ of the Information Commission Regulation Number 1 Year 2013 concerning Public Information Dispute Resolution Procedures states that there is a legal position for the Petitioner to submit a request for information dispute resolution. Legal rules that exist in Decision No. 509/K/TUN/2013 states that there must be a consideration whether the plaintiff's interests have implications on their legal standing. This provision is in accordance with the principle of point d'interest point d'action as referred to in Article 53 paragraph (1) of the Law of State Administrative Courts, namely that the Petitioner must have the legal interest that has been significantly harmed.

The State Administrative Courts Judges prioritized substantive justice over formal justice by stating the principle of personal responsibility,

18 Ni Luh et al., "Logika Hukum dan Terobosan Hukum Melalui Legal Reasoning," Jurnal Hukum Jatiswara 31, no. 1 (2016): 99-110. namely individuals or institutions being responsible for their own mistakes. This jurisprudence initially appeared in decision No. 54/K/TUN 2014 which was subsequently followed by case decisions Number 193/PK/TUN/2017 and 533 K/TUN/2017. Then, the Supreme Court's stance also confirmed this in the Supreme Court Circular Letter Number 1 Year 2017 concerning the Enforcement of the Formulation of the 2017 Supreme Court Chamber Plenary Meeting as Implementation Guidelines for Court Duties ${ }^{19}$. Substantive justice is an important matter that must be prioritized when it conflicts with formal justice. This is based on the consideration that formal justice is implemented to uphold substantive justice.

The plaintiff's legal interests are the starting point for filing a lawsuit. This is made clear in Article 1 number 9 of Law Number 51 Year 2009 concerning the Second Amendment to Law Number 5 Year 1986 concerning State Administrative Courts and Article 53 paragraph (1) of Law Number 5 Year 1986 concerning State Administrative Courts. This is used as a form of confirmation of the principle of point d'interest point d'action and the flow of tight standing, namely that those who are mentioned in the decree are the parties who can file a lawsuit.

The extension of the legal meaning of the word "interest" is of great importance. The extension of the meaning of this word opens wider opportunities for the society to obtain justice without any restrictions as in the current Law of State Administrative Courts. Anyone who feels that their legal interests have been harmed can submit an application or lawsuit to the court. The interests that are harmed will certainly have an impact on the disadvantaged legal position. This must be emphasized in the relevant legislation.

The provisions of Article 4 of Law Number 14 Year 2008 which state that everyone has the right to obtain public information and can be interpreted as actio popularis, needs to be harmonized with the contents of Article 1 number 9 and Article 53 of the Law of State Administrative Courts. Adjustment to the meaning of "everyone" needs to be reviewed by taking into account social changes in society. If an action popularis principle is used in the legislation regarding State Administrative Law, a comprehensive change must be made so as not to cause confusion for the society.

19 "Putusan Mahkamah Agung Republik Indonesia." 
The judges will consider carefully before giving the final decision, namely in the section of legal considerations where the judges provide an explanation using logic, reasoning and legal arguments based on examination of disputes to give a fair decision. Judges carry out thinking activities based on legal logic, experience and knowledge. This thought process is based on certain parameters ${ }^{20}$. First, thinking broadly using certain legal patterns and rules. Second, reasoning must be analytical in which reasoning is carried out using legal logic to analyze the filed problems.

To analyze the problems that arise, policies are needed in order to give fair and useful decisions. In the preparation of state administrative decisions, the principle of discretion also needs to be used, even though the principle of discretion is not listed as one of the principles in the General Principles of Good Governance. However, by taking into account the development of legislation and government, the principle of discretion can be used as General Principles of Good Governance. The principle of discretion was stated in the Algemene beginselen van behoorlijk bestuur put forward by the Commission of de Monchy and was not accepted by the parliament at that time. The application of the general principle of good governance universally is still carried out, by taking into account Pancasila, politics and socio-culture so that it can be called using other names but still does not reduce the meaning of this principle ${ }^{21}$. Although normatively the principle of discretion is not included, in the running of government, this should be the basis for administering the government before issuing a state administrative decision.

Building good logic, reasoning and legal arguments for a judge is very important, especially those that can lead to new legal rules. Legal reasoning is widely used for various activities in the field of law, including identification of cases, interpretation, choice of law, considerations, opinions and legal opinions. Legal reasoning is the application of valid and precise thinking

\footnotetext{
2o Tri Rahayu Utami and Aditya Yuli Sulistyawan, "Urgensi Penalaran Dalam Argumentasi Hukum Guna Mengembangkan Pemikiran Hukum Yang Komprehensif," Jurnal Crepido o1 (2019): 32-39.

${ }_{21}$ M. Zamroni, "General Principles of Good Governance in Indonesia: What Are The Legal Bases?," Varia Justicia 15, no. 1 (2019): 1-8.
}

from legal logic, to then do deduction and induction reasoning ${ }^{22}$. The results of the research by Urbanus Ura Weruin used the opinion of Lon Fuller who developed the IRAC legal reasoning method, namely issue, rule of law, argument and conclusion, which prioritizes analysis based on problems and legal rules so as to produce conclusions.

State Administrative Courts Judges will conclude the object of dispute. Then, they will assess the subject matter of the dispute whether there is a juridical defect regarding authority, procedure and substance, assess the relevance of legal provisions and carry out legal reasoning to determine whether the facts are in accordance with the legal rules. In examining and deciding cases, the State Administrative Courts Judge must be based on two important things. First, namely formal law in the form of legal rules governing procedures for examining and adjudicating a case. Second, namely material law to achieve substantial justice $^{23}$. Formal law contains the formality of a lawsuit, absolute and relative competence and a grace period for filing a lawsuit as regulated in the laws regarding the state administrative procedure law. Material law comes from laws and regulations and unwritten laws that exist in society. This is in line with Article 5 paragraph (1) of Law Number 48 Year 2009 concerning Judicial Power.

Providing decisions that have procedural and substantial justice is not an easy thing. This is because the three legal values, namely justice, legal certainty and benefits, are difficult to realize together. When the decision is closer to legal certainty, automatically, the verdict decision moves away from justice. If you prioritize the principle of justice, it means that you have to consider the customs and laws that live in society. Meanwhile, the principle of legal certainty emphasizes the principle that creates order in society ${ }^{24}$. Judges must be able to create proportionality between

${ }_{22}$ Urbanus Ura Weruin, "Logic, Reasoning and Legal Argumentation," Jurnal Konstitusi 14, no. 2 (2017): 374-395.

23 Enrico Simanjuntak, "Perihal Putusan Pengadilan Dan Upaya Hukum," in Hukum Acara Peradilan Tata Usaha Negara : Transformasi Dan Refleksi (Jakarta: Sinar Grafika, 2018), 257.

24 Isdiana Kusuma Ayu Abid Zamzami, "Filosofi Penemuan Hukum Dalam Konstruksi Putusan Mahkamah Agung No 46 P/HUM/2018," Jurnal Hukum Peratun 2, no. 1 (2019): 75-97. 
justice, benefit and legal certainty, even though this is difficult to implement in making a final decision.

\section{B. The Role of State Administrative Courts to Obtain Access to Justice for Society}

According to the Rechtsstaat concept, the State Administrative Courts formed as one of the elements of the rule of law carries out the function of judicial control on government performance which is external and a-posteriori and assesses the legality of government actions. Rule of law and rechtsstaat have different consequences in relation to the judicial system being applied. Meanwhile, State Administrative Courts in the rule of law of Pancasila, of course, has different characteristics, namely keeping the relationship between individual interests and people's interests balanced.

Based on the legal comparation approach, the position of State Administrative Courts in Indonesia is different from France where France adheres to a duality of jurisdiction. As stated by Auby, there are two judicial systems in France, namely ordinary courts and administrative courts where administrative courts (tribunaux administrative) culminate in the Counseil d'Etat or the Council of State and separate from the ordinary courts ${ }^{25}$. Meanwhile, the rule of law system in England adheres to a unity of jurisdiction where all judicial bodies culminate in the High Court and do not know administrative courts in particular. The State Administrative Courts system in Indonesia is interesting because it does not fully follow the administrative courts system in countries that adhere to the Civil Law System, namely duality of jurisdiction, but rather leads to the concept of unity of jurisdiction. State Administrative Courts in Indonesia tend to prefer the concept of Civil Law System, namely by placing government officials who are not equal in court ${ }^{26}$. In view of the position of State Administrative Courts, which can be called a hybrid system, the State Administrative Courts in Indonesia as

25 Dani Habibi, "Perbandingan Hukum Peradilan Tata Usaha Negara Dan Verwaltungsgerecht Sebagai Perlindungan Hukum Rakyat," Kanun Jurnal Ilmu Hukum 21, no. 1 (2019): 1-22.

26 Umar Dani, "Memahami Kedudukan Pengadilan Tata Usaha Negara di Indonesia : Sistem Unity of Jurisdiction Atau Duality of Jurisdiction?," Jurnal Hukum dan Peradilan 7, no. 3 (2018): 405-424. an institution follow the Common Law system, culminating in the Supreme Court, but in dispute resolution procedures, the State Administrative Courts follow the Civil Law system, especially in the Netherlands. This confirms that the differences between the current Civil Law and Common Law systems are no longer prioritized.

The universal principle used is the independence of judiciary or freedom and impartial judiciary in which the judicial body has freedom from any influence to examine, decide and resolve disputes. Freedom of judicial power means freedom from political influence in resolving disputes. This is a rule of law requirement, both in the civil law system and in the common law system. Mahfud MD emphasized that the principle of independence of judiciary is an important feature of a democratic rule of law, so that no country is called a democratic country without the practice of independent judicial power ${ }^{27}$.

The important role of State Administrative Courts in state administrative law enforcement is very strategic. First, namely as a control agency over government administration actions. Second, namely providing legal protection to the society from government legal action in the field of public law. In line with the state's goal of protecting the entire Indonesian nation and all Indonesian people, this is manifested in the form of a judicial body as one of the main elements of a rule of law.

Legal protection by State Administrative Courts is legal protection that is repressive in nature, namely resolving disputes. According to Paulus Effendi Lotulung, every country has a method and system to provide legal protection. This is emphasized by Sjachran Basah who states that legal protection has two sides, namely for citizens and government administration ${ }^{28}$. To be able to carry out this function, legal protection is provided through administrative and court measures with arrangements that have been stipulated in legislation.

At the beginning of the establishment of the State Administrative Courts, the absolute competence possessed was narrow so that it was

27 Kasman Abdullah Romi Librayanto, Marwati Riza, Muhammad Ashri, "Penataan Kewenangan Mahkamah Konstitusi Dalam Memperkuat Kekuasaan Kehakiman," Amanna Gappa 27, no. 1 (2019): 43-66.

28 Maftuh Effendi, Dinamika Yurisdiksi Peradilan Administrasi (Jakarta: Pusaka Media, 2017). 
unable to provide maximum legal protection to citizens. This is because the State Administrative Courts only examines state administrative disputes with the object of state administrative decisions which have concrete, individual, final characteristics and have legal consequences for citizens and civil legal entities. The narrow absolute competence also narrows access to justice for citizens who actually get rights to justice.

Constitutionally, the rights of citizens to obtain recognition, guarantees, protection and legal certainty which is fair as well as equal treatment before the law are regulated in Article 28 D paragraph (1) of the 1945 Constitution. The rights of citizens to obtain justice include the availability of information that is easily accessible and easily understood by citizens, receiving appropriate legal assistance, and understanding the litigation process in court. In addition to this, people who experience obstacles to access to justice can also arise due to economic, educational and gender issues.

After the reform began, the public began to see the role of the State Administrative Courts more often. This can be seen from the number of disputes examined in relation to political parties, public information disclosure, the environment, regional heads election, employment, auction, legal entities and licensing. In Decision Number 195/G/KI/2020/PTUN.Jkt, the Panel of Judges decided that the Petitioner's objection was not accepted because they did not have legal standing. The element of interest that is harmed becomes important, although it does not have a direct implication for the legal interest. It is necessary to study further regarding the possibility of drafting laws and regulations regarding citizen lawsuit in the State Administrative Courts. However, this is done with due regard to developments in the dynamics of law and society. The condition of society which begins to realize that every citizen has the same rights before the law and government is one of the factors in increasing awareness to obtain protection and law enforcement, recognition and protection of human rights from the state. The General Principles of Good Governance can be used as a basis for the government in formulating decisions, as a touchstone for the object of a lawsuit filed by citizens and to provide legal protection for the society in the event of a detrimental government decision and/or action. Legal protection provided in the form of legal aid is regulated in Articles 144C and 144D of Law Number 51 Year 2009 concerning the Second Amendment to Law Number 5 Year 1986 concerning State Administrative Courts. This regulates legal aid provided by the State which can be accessed free of charge and easily. The same thing is also regulated in Law Number 49 Year 2009 concerning the Second Amendment to Law Number 2 Year 1986 concerning General Courts.

The new paradigm in government administration in Indonesia came with the passing of Law Number 30 Year 2014 concerning Government Administration (hereinafter referred to as the AP Law) which gave an expansion of absolute competence to the State Administrative Courts. As stated by Dani Elpah, therehasbeena big bang after the Law of Government Administration came into effect in relation to the change in the meaning of state administrative decisions as objects in the State Administrative Courts. This is in line with Enrico's opinion, namely that there is a de-reconstruction of the legal criteria for the object of dispute in State Administrative Courts ${ }^{29}$. The Supreme Court Circular Letter Number 4 Year 2016 states that the nature or characteristics of the object of the lawsuit after the Law of Government Administration is passed are concrete-individual, abstract-individual and concrete-general.

The expansion of the absolute competence of the State Administrative Courts shows that it can provide maximum legal protection against government actions in accordance with the demands of the times ${ }^{30}$. The same thing was stated by Tri Cahya Indra Permana, that the vacuum that cannot be entered by the society has encouraged the opening of access to justice by the Law of Government Administration, both in terms of material and the plaintiff's legal subject ${ }^{31}$. It is hoped that it can provide justice for the society.

29 Enrico Simanjuntak, "Pergeseran Kompetensi Absolut Peradilan Umum Kepada Peradilan Administrasi Pasca Pengesahan UU No.30 Tahun 2014," in Kewenangan Peradilan Tata Usaha Negara Mengadili Perbuatan Melawan Hukum Pemerintah (Depok: PT Rajagrafindo Persada, 2021), 185.

3o Supandi, "Modernisasi Peradilan Tata Usaha Negara Di Era Revolusi Industri 4.o Untuk Mendorong Kemajuan Peradaban Hukum Indonesia," Jurnal Hukum Peratun 2, no. 2 (2019): 124-149.

${ }^{31}$ Tri Cahya Indra Permana, "Perihal Kewenangan Penilaian Unsur Penyalahgunaan Wewenang," in Catatan Kritis Terhadap Perluasan Kewenangan Mengadili Peradilan Tata Usaha Negara (Yogyakarta: Genta Publishing, 2016), 48-67. 
Aristotle divides justice according to proportion or balance. Distributive justice refers to the sharing of the same goods to the same person, otherwise different people will also receive different shares. Corrective justice requires compensation or restoration of the situation as before as a means to balance the imbalances due to injustice ${ }^{32}$. In a rule of law, distributive justice is a form of state protection for its citizens to obtain what a citizen demands from another citizen. This is in line with the expansion of the absolute competence of the State Administrative Courts so as to make it easier for citizens to obtain justice. The right of citizens to demand justice to the state from detrimental legal actions by the Government can be implemented because its legality has been guaranteed in law.

The legal criteria for the object of a dispute that can be sued at the State Administrative Courts have undergone several extensions. First, a request for an examination of abuse of authority can be submitted based on Article 21 of the Law of Government Administration. Second, citizens can file lawsuits for factual actions of the Government based on Article 87 of the Law of Government Administration. The application for an assessment of the element of abuse of authority and claims for factual action will be reviewed using the provisions of Article 53 paragraph (2) of Law Number 9 Year 2004 concerning Amendments to Law Number 5 Year 1986 concerning State Administrative Courts where this is contrary to the applicable laws and regulations and contradicts the General Principles of the Good Governance. Submission of a request for an assessment of the element of abuse of authority shows that if there is an assessment stating that there has been an abuse of authority, then this matter should be examined by the State Administrative Courts. This is because it is related to the authority possessed by the Official and as a touchstone for the actions that are requested to be assessed. Based on the case decision No. 09/P/PW/2018/ PTUN.Srby and No. 2/P/PW/2017/PTUN.JBI, reviewing the applicant's actions. Based on the General Principles of Good Governance, it means that the applicant in issuing state administrative decisions

32 Zakki Adlhiyati and Achmad Achmad, "Melacak Keadilan Dalam Regulasi Poligami: Kajian Filsafat Keadilan Aristoteles, Thomas Aquinas, Dan John Rawls," Undang: Jurnal Hukum 2, no. 2 (2019): 409-431. is based on the principle of accuracy, the principle of not abusing authority. Lawsuits for factual actions in the field of public law in examination by State Administrative Courts are still based on the General Principles of Good Governance, namely the principle of accuracy. The laws and regulations that are violated are as a touchstone for the object of the dispute (see case Number 99/G/2020/PTUN. Jkt and case Number 220/G/2019/PTUN.Jkt).

According to Yodi Martono, several provisions in Law Number 30 Year 2014 concerning Government Administration provide an opportunity to expand the absolute competence of the State Administrative Courts which should be done by laws (bij de wet) and not by inserting it into laws (in de wet) ${ }^{33}$. The expansion of the absolute competence of judicial body should be affirmed in the laws governing the State Administrative Courts. However, on the other hand, there has not been any new laws related to this matter so that it is inserted in another law. This is actually not correct. The government needs to make new laws on State Administrative Courts by considering the development of state administrative law, the dynamics of society and as a harmonization step with Law Number 30 Year 2014 concerning Government Administration.

Expansion of the absolute competence of the State Administrative Courts can be done by drafting new laws and regulations regarding State Administrative Courts and following the provisions of Law Number 12 Year 2011 concerning the Establishment of Laws and Regulations in conjunction with Law Number 15 Year 2019 concerning Amendments to Law Number 12 Year 2011 concerning Establishment of Laws and Regulations.

The society is increasingly given the ease of obtaining justice. Nonetheless, this is supported by a legal structure linked to appropriate or mutually supportive laws and regulations. Meanwhile, in terms of legal culture, this certainly requires an adjustment process both by the society and law enforcers who are directly involved.

Access to justice for the society to be able to obtain justice through the State Administrative

33 Yodi Martono Wahyunadi, "Kompetensi Absolut Pengadilan Tata Usaha Negara Dalam Konteks Undang-Undang No. 30 Tahun 2014 Tentang Administrasi Pemerintahan," Hukum Dan Peradilan 5, no. 1 (2016): 135-154. 
Courts is also followed and encouraged by arrangements to be able to litigate electronically. The Supreme Court has started to use the development of the Electronic Court File System for applications for cassation and judicial review as outlined in the Supreme Court Circular Letter Number 1 Year 2014 dated January 29, 2014 concerning Amendments to Circular Letter Number 14 Year 2010 concerning Electronic Documents as Completion of Cassation and Judicial Review Applications.

The development that can be used by the society to be able to litigate electronically is confirmed in the Supreme Court Regulation Number 3 Year 2018 concerning Electronic Case Administration in Courts which is further amended by the Supreme Court Regulation Number 1 Year 2019 concerning Electronic Case and Trial Administration. This is expected to further facilitate access to justice for the society.

\section{CONCLUSIONS}

The development of the State Administrative Courts Judge jurisprudence in state administrative law is highly needed to develop the legal rules in the field of administrative law. The jurisprudence of State Administrative Courts Judge must be easily accessible for the government as state administrators, citizens and for the State Administrative Courts Judges. The role of the State Administrative Courts Judge's decision is important for the development of state administrative law. This is based on several things. First, a the State Administrative Courts Judge's decision can form a new legal rule that is used in state administrative law. This is due to the dynamic nature of the Judge's decision originating from a dispute. Second, the process of examining disputes and making a decision takes less time than the legislative process. Third, the State Administrative Courts Judge's decision is a means to make changes in society which allows the submission of citizen lawsuit to the State Administrative Courts.

In terms of access to obtain justice, the broader absolute competence of the State Administrative Courts can be understood in several ways. First, to provide wider opportunities for the society to obtain justice due to losses arising as a result of the Government's legal actions. Second, the lawsuit filed is not only a cancellation of state administrative decisions, but also a lawsuit against factual actions of the government stemming from public legal actions by the Government. Third, it is easier for the society to gain access to justice, namely through the existence of an electronic court (e-court).

\section{SUGGESTION}

In order for jurisprudence to play a more role in the development of state administrative law, it is necessary to develop a system related to the process of selecting Judges' decisions. It can be used as a source of law for the Government, Judges and society. In order to further increase the effectiveness of jurisprudence, it is necessary to consider that a collection of jurisprudence can be provided to the government so that it can improve the quality of government administration.

It is necessary to formulate a new Law concerning State Administrative Courts so that there will be compliance of regulations. This is so that it is more synchronized with other laws and regulations for filing citizen lawsuit can keep up with the times.

\section{ACKNOWLEDGMENT}

The researcher would like to thank the Head of the Faculty of Laws of Diponegoro University who gave the opportunity to conduct this research.

\section{BIBLIOGRAPHY}

Abdoellah, Priyatmanto. Revitalisasi Kewenangan PTUN Gagasan Perluasan Kompetensi Peradilan Tata Usaha Negara. Yogyakarta: Cahaya Atma Pustaka, 2016.

Abid Zamzami, Isdiana Kusuma Ayu. "Filosofi Penemuan Hukum Dalam Konstruksi Putusan Mahkamah Agung No $46 \mathrm{P} /$ HUM/2018." Jurnal Hukum Peratun 2, no. 1 (2019): 75-97.

Adlhiyati, Zakki, and Achmad Achmad. "Melacak Keadilan Dalam Regulasi Poligami: Kajian Filsafat Keadilan Aristoteles, Thomas Aquinas, Dan John Rawls." Undang: Jurnal Hukum 2, no. 2 (2019): 409-431.

Bhakti, Teguh Satya. "Pembangunan Hukum Adminisitrasi Negara Melalui Pemberdayaan 
Yurisprudensi Peradilan Tata Usaha Negara.” Universitas Diponegoro, 2017.

Chandranegara, Ibnu Sina. "Pengadopsian Mekanisme Fast-Track Legislation Dalam Pengusulan Rancangan Undang-Undang Oleh Presiden." Jurnal Penelitian Hukum De Jure 21, no. 1 (2021): 123.

Dani, Umar. "Memahami Kedudukan Pengadilan Tata Usaha Negara Di Indonesia : Sistem Unity Of Jurisdiction Atau Duality Of Jurisdiction? Sebuah Studi Tentang Struktur Dan Karakteristiknya." Jurnal Hukum dan Peradilan 7, no. 3 (2018): 405-424.

Elisabeth Putri Hapsari, Lapon Tukan Leonard, Ayu Putriyanti. "Kewenangan Hakim Peradilan Tata Usaha Negara Menggungakan Asas Ultra Petita Berdasarkan Putusan Mahkamah Agung No.5//K/TUN/1992 (Studi Kasus Putusan No. 32/G/2012/PTUN. Smg)." Diponegoro Law Journal 6, no. 2 (2017): 1-13.

Enrico Simanjuntak. "Relevansi Pemikiran Negara Hukum Dalam Diskursus Keadilan Administratif Kontemporer." In Rekonseptualisasi Kewenangan Pengadilan Tata Usaha Negara Dalam Mengadili Perkara Fiktif Positif, 61. Depok: PT Rajagrafindo Persada, 2021. http://www. rajagrafindo.co.id.

Erwinsyahbana, Tengku, and Tengku Rizq Frisky Syahbana. "Perspektif Negara Hukum Indonesia Berdasarkan Pancasila" (2018): 120. https://osf.io/preprints/inarxiv/cwev7/.

Firdaus, Insan. "Harmonisasi UndangUndang Narkotika Dengan UndangUndang Permasyarakatan Terkait Rehabilitasi Narkotika Bagi Warga Binaan Pemasyarakatan (Harmonizing The Narcotics Law with Correctional Laws Concerning The Rehabilitation of Narcotics for Prisoners)." Jurnal Penelitian Hukum De Jure 21, no. 1 (2021): 141-160.

Habibi, Dani. "Perbandingan Hukum Peradilan Tata Usaha Negara Dan Verwaltungsgerecht Sebagai Perlindungan Hukum Rakyat." Kanun Jurnal Ilmu Hukum 21, no. 1 (2019): $1-22$.
Heryansyah, Despan, and Kus Pratiwi. "Perluasan Kompetensi Absolut Pengadilan Tata Usaha Negara Dalam Undang-Undang Administrasi Pemerintahan." Jurnal Hukum Ius Quia Iustum 25, no. 2 (2018): 339-358.

Hulman Panjaitan. "Keberadaan Hukum Adat Dalam Yurisprudensi." Jurnal Hukum tô-râ 2, no. 3 (2016): 413-420.

Luh, Ni, Putu Vera, Dosen Fakultas, and Hukum Universitas. "Logika Hukum dan Terobosan Hukum Melalui Legal Reasoning." Jurnal Hukum Jatiswara 31, no. 1 (2016): 99-110.

Maftuh Effendi. Dinamika Yurisdiksi Peradilan Administrasi. Jakarta: Pusaka Media, 2017.

Romi Librayanto, Marwati Riza, Muhammad Ashri, Kasman Abdullah. "Penataan Kewenangan Mahkamah Konstitusi Dalam Memperkuat Kekuasaan Kehakiman.” Amanna Gappa 27, no. 1 (2019): 43-66.

Simanjuntak, Enrico. "Peran Yurisprudensi Dalam Sistem Hukum Di Indonesia The Roles of Case Law in Indonesian Legal System." Jurnal Konstitusi 16, no. 1 (2018): 83-104.

_. "Pergeseran Kompetensi Absolut Peradilan Umum Kepada Peradilan Administrasi Pasca Pengesahan UU No.30 Tahun 2014." In Kewenangan Peradilan Tata Usaha Negara Mengadili Perbuatan Melawan Hukum Pemerintah, 185. Depok: PT Rajagrafindo Persada, 2021.

"Perihal Putusan Pengadilan Dan Upaya Hukum." In Hukum Acara Peradilan Tata Usaha Negara: Transformasi Dan Refleksi, 257. Jakarta: Sinar Grafika, 2018.

- "Praktik Yurisprudensi Dan Kepastian Hukum Dalam Sistem Civil Law." In Perdebatan Hukum Administrasi Sebuah Kompilasi Artikel Hukum Administrasi, 3060. Jakarta: Gramata Publishing, 2017.

Supandi. "Modernisasi Peradilan Tata Usaha Negara Di Era Revolusi Industri 4.0 Untuk Mendorong Kemajuan Peradaban Hukum Indonesia." Jurnal Hukum Peratun 2, no. 2 (2019): 124-149.

Syuhada, Otong. "Karakteristik Negara Hukum Pancasila Yang Membahagiakan Rakyatnya." 
Presumption of Law 3, no. April (2021): $1-18$.

Theresia Ngutra. "Hukum Dan Sumber-Sumber Hukum.” Jurnal Supremasi XI, no. 2 (2016): 193.

Tri Cahya Indra Permana. "Perihal Kewenangan Penilaian Unsur Penyalahgunaan Wewenang." In Catatan Kritis Terhadap Perluasan Kewenangan Mengadili Peradilan Tata Usaha Negara, 48-67. Yogyakarta: Genta Publishing, 2016.

Utami, Tri Rahayu, and Aditya Yuli Sulistyawan. "Urgensi Penalaran Dalam Argumentasi Hukum Guna Mengembangkan Pemikiran Hukum Yang Komprehensif." Jurnal Crepido 01 (2019): 32-39.

Weruin, Urbanus Ura. "Logic, Reasoning and Legal Argumentation.” Jurnal Konstitusi 14, no. 2 (2017): 374-395.

Yodi Martono Wahyunadi. "Kompetensi Absolut Pengadilan Tata Usaha Negara Dalam Konteks Undang-Undang No. 30 Tahun 2014 Tentang Administrasi Pemerintahan." Hukum Dan Peradilan 5, no. 1 (2016): 135154.

Yonas Bo'a, Fais. "Pancasila Sebagai Sumber Hukum Dalam Sistem Hukum Nasional Pancasila as the Source of Law in the National Legal System." Jurnal Konstitusi 15, no. 1 (2018): 28-49. http://consrev.mkri. id/index.php/jk/article/view/1512.

Zamroni, M. "General Principles of Good Governance in Indonesia: What Are The Legal Bases?" Varia Justicia 15, no. 1 (2019): 1-8.

"Putusan Mahkamah Agung Republik Indonesia." https://jdih.mahkamahagung.go.id/index. php?option $=$ com_remository \&Itemid $=46 \& \mathrm{f}$ unc $=$ fileinfo\&id $=4017$ 